\title{
Automatic Drip Irrigation using Solar Energy
}

\author{
Venkumar P, Sureshkrishna K, Vignesh N, Sundaramoorthy K, Muthu Kumaran E
}

\begin{abstract}
The proper usage of water is essential in irrigation because of the shortage of water. The shortage of water is due to lack of rain and continuous supply of water for irrigation as a result lot of water got wasted. It is very much essential to manage the use of water efficiently. The main objective in this project is to watering crops automatically by monitoring soil moisture for supply water based on the requirement and to maintain the water level in the overhead tank. This system suits for all climatic conditions. This project proposed on the usage of automatic irrigation system based on Arduino board, soil moisture sensor, float switch and solar panel. This automatic irrigation system senses the moisture content of the soil and automatically switches the solenoid valve and the overhead water level is monitor by float switch sensor and the power the required for the entire system is generated by using the solar panel. It will automatically control the water level in the tank also. The Global system for mobile communication (GSM) module sends the message, whenever the valve is turn $O N$ and OFF. This project is fully automatic to support farmers, provides water as required, deploys renewable energy, minimize man power, less space, low cost and user friendly.
\end{abstract}

Keywords: Automated drip Irrigation system, Solar panel, Arduino board, Soil moisture sensors

\section{INTRODUCTION}

Irrigation is the process of operation of the water to flow over lands for dry ground plants. There are many methods of irrigation prevails, the most important work of irrigation is to supply the water to the plants. The water should spread uniformly into the lands and it seems to be good for each and every crop and its growth. Few methods of irrigations are

\section{A. Surface Irrigation}

Surface irrigation method is one of the old methods and it is followed by the formers many years. Nowadays also it is following by the farmers. In this system a certain amount of water surrounds the whole agriculture land to make it wet and penetrate into the soil. It is furrow border strip or basin

Revised Manuscript Received on December 30, 2019.

* Correspondence Author

Venkumar P*, Professor, Department of Mechanical Engineering, Kalasalingam Academy of Research and Education, Krishnankovil, Tamil Nadu, India. p.venkumar@klu.ac.in

Sureshkrishna K, UG Student, Department of Mechanical Engineering, Kalasalingam Academy of Research and Education, Krishnankovil, Tamil Nadu, India.

Vignesh N, UG Student, Department of Mechanical Engineering, Kalasalingam Academy of Research and Education, Krishnankovil, Tamil Nadu, India.

Sundaramoorthy K, UG Student, Department of Mechanical Engineering, Kalasalingam Academy of Research and Education, Krishnankovil, Tamil Nadu, India.

Muthukumaran E, Associate Professor, Department of Electronic and Communication Engineering, Dr.B.R.Ambedkarinstitude of Technology Andaman,India

irrigation when it leads to flooding of the cultivated lands. Still this method is active. The water levels are controlled by devices usually plugged by soil it is applied and rms do not have to be defined. Do not use abbreviations in the title or heads unless they are unavoidable. Mostly in rice, paddies sometimes the water is poured by human to the level of the lands.

\section{B. Drip Irrigation}

Drip irrigation is also called trickle irrigation. It is a system which can be flow water drop by drop directly at the roots. By this system water has been sent plants of the root zone. This method has been increasing the growth of all seeds and plants moreover it is the most water efficient method. In this method water can be distributed through pipes, emitter, tubing and valves. It is so far better than surface irrigation. The Fig. 1 represents drip irrigation system.

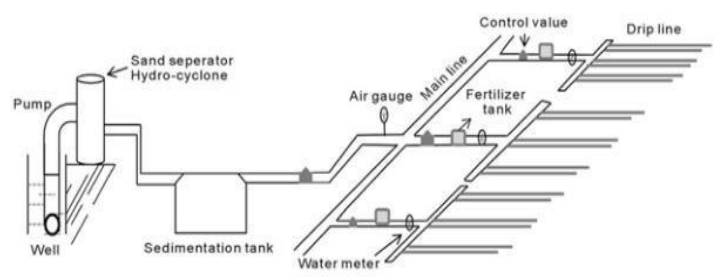

Fig.1 Drip Irrigation system [16]

\section{Sprinkler Irrigation:}

In this method water pipes are fixed into the fields at various locations in the land then the water can be flow through the high pressure sprinklers from overhead. High pressure sprinklers that rotate and a hose sprinklers mounted moving platform and connected to the water source.

Sprinklers can be mounted on moving platform is connected in the water through a hose. Travel sprinklers are an automatic moving wheeled system. As the tubing is wound on the drum powered by the irrigation water, the sprinkler is pulled across the field. When the sprinkler is back at the reel of the system shuts off. This type of system is known as water reel travelling irrigation sprinkler and they are used for dust suppression, irrigation, and land application of waste water. Fig. 2 shows the sprinkler irrigation.

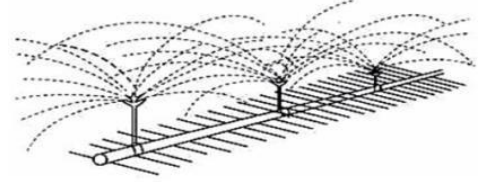

Fig.2 Sprinkler irrigation system [15] 


\section{Advantages of drip irrigation}

- It is possible to grow good crops to the cultivator.

- It improves the groundwater level.

- It increases the yields of crops that provide more income for the cultivators.

- It improves the growth of crops during the rainy season.

\section{E. Solar Energy}

It is a renewable energy technique. Energy can be gained from the sun. Sun has the power to emit the large amount of heat that can be turned into energy and it called as solar heating.

Sunlight is converted into electricity, with help of solar plate or directly by using photo voltaic (PV), or concentrated solar power (CSP). CSP systems convert sunlight into electric current, which consist of lenses or mirrors and tracking systems to absorb large area of sunlight by photoelectric effect.

\section{F. Advantages of solar energy:}

- Photovoltaic systems provide less noise.

- Small-scale solar plants are placed in a rooftop that

- Reduces the space. Solar energy is an easily available renewable resource. This reduces environmental impacts.

- PV systems are available at any size based on energy requirements.

\section{G. Automatic Irrigation}

Automatic irrigation system which is very quiet and work well in manner in this system once it is installed in the agricultural land. It can be operated by automatically and moreover it there is no need of human being permanently. It has so many drawbacks to use such as highly expensive complicated to work. It is hard to implement it. The categories of automation are three types. They are as follows:

- Automatic irrigation system

- Solar powered system

- GSM based irrigation system

\section{H. Automatic Irrigation System}

The most probable work of an automatic irrigation is moisture the soil and intended for the development of irrigations. The merits of this system are tomanage the man power and make good irrigation. The microcontroller8051 is programmed that receives the signal from the sensing material. The op-amp which is act as comparator that interface between the sensing materials. The soil moisture condition is transferred by microcontroller. The automatic irrigation is shown in Fig. 3.

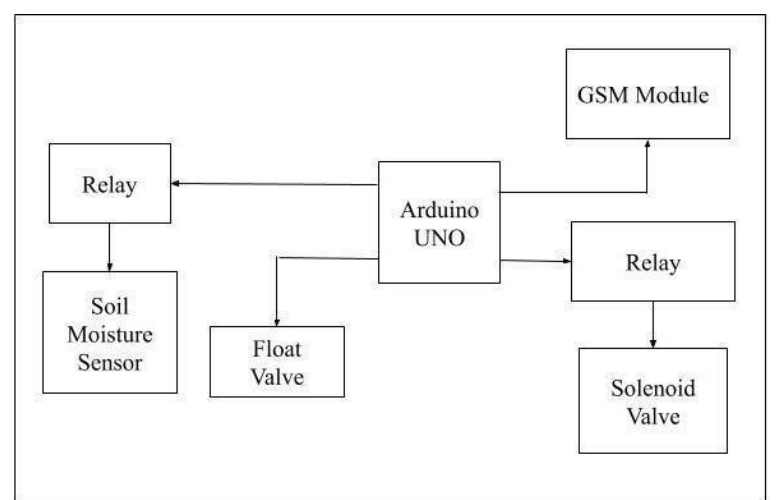

Fig3 Automatic irrigation system

\section{Solar Powered System}

This system consists of solar panel as a power unit. In agricultural areas, the proper usage of water is required. Automatic irrigation method is needed due to lack of the water. The water level is getting reduced from the ground due to continuous heat and thus the result is water scarcity. In the irrigation system, solar energy produced from the panels is used to operate this irrigation system. The circuit combines moisture sensors by using op-amp IC. The op-amp is act as comparators. Two stiff copper wires are dip into the soil to get the condition of the soil whether it is dry or wet. For charging the photovoltaic cells charge controller is used in the solar system to the entire circuit. The Fig. 4 shows the solar power system.

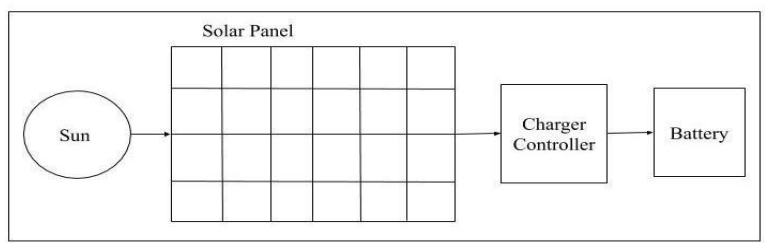

Fig4 Solar power systems

\section{J. GSM Based Irrigation System}

Now a day farmers are hard to irrigate due to lack of man power, highly expensive labor cost and water scarcity the farmers are the same method of irrigation system. To minimize this problem, we have developed a new system by using GSM technology. From the GSM based automatic irrigation system we identify the operation in the cropping areas through SMS using GSM module. The Fig. 5 represents the GSM based irrigation system.

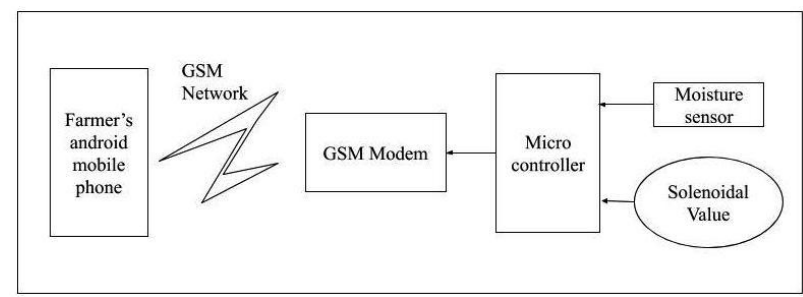

Figure 5 GSM based irrigation system 


\section{LITERATURE REVIEW}

\section{A. Solar Energy}

Solar energy is absorbed by the solar panel. Photovoltaic modules are absorbing light energy (photons) through the Sun rays to create electricity through the photovoltaic effect. Solar panel is used in our project.

Moriarty and Michael [1] investigated about the solar receiver. A solar receiver that receives Sun rays directed thereto. The working fluid is in a heat pipe and that pipe is in a receiver. The heated air is flow through a power generation device. The heat energy is converted into electrical energy. Its construction is simple and install in our homes.

Costello et al. [2] used black fluids to observe the solar heat and provide heat energy. The heat energy is converted into electrical energy. There is a basic of solar heating system. It is easily construct and produce the electric energy.

Raghunathan et al. [3] discussed the Environmental energy harvesting, in particular solar based, has emerged as a viable technique to supplement battery supplies. It can embed

Northrup and Leonard [4]are using the compound lens is used in the solar system. The lens is facing to the suns and it can produce the heat energy. The lens is carrying the sun ray and its extract to the heat element. The power generation is very less.

\section{B. Drip Irrigation}

Drip irrigation is one of the methods for irrigation to control the water flow and It is directly delivered to the root side of multiple plants. The water is either dripped onto the surface above the roots and its helps to reduce soil erosion, provide uniform water flow and reduce the wastage of water. Drip irrigation is main part of instead of our project.

Hossain and Lixue[5]investigated the review of drip irrigation system. In current situation the drip irrigation system is used for optimum utilization of water. So, it will be help of small farmers and reduce the wastage of water.

Wazeda and Hughesa[6]are used PV solar panel and motor in the system. It sucked the underground water to ground level. It is manual operating system. It helps our farmers.

Postel et al. [7] investigate drip irrigation for small farmers. This generation is using drip irrigation because level water is very low. So the farmers are using drip irrigation system. But the low investment farmers are wasting more water. So, it will be help of small farmers and reduce the wastage of water.

\section{Automation}

The technique of making an apparatus, a process, or a system operate automatic system iscalled automation. In the creation and application of technology to monitor and the devices controlled by the operator. Our project is used automation in drip irrigation based on sensor and valve.

Gayathri et al. [8] used biometric system for secured data exchange the fingerprint biometric would be a good choice for biometric application because they are unique for a to the gardens.

person. Fingerprint is a prominent technology for use in various applications such as forensic, access control and military applications.

McNally [9] introduced Mat lab interface in with a household power for non-invasive current meter is called as Arduino based wireless power meter. To provide a clear picture of a home's current usage and through this data provide an estimate to power consumptions these are the principles. It should be help of our Government Electricity Board workers.

Anwaarullah and Altaf [10] used the openness, flexibility and special features in the android. It has been widely adopted in applications beyond just Smart phones. Real-time operating system (RTOS) software is used in this system. Only authorized users to control the appliances by using pattern based password protection system.

\section{III.PROBLEM DESCRIPTION}

The current scenario of watering plant have some drawbacks, that is soil erosion, un uniformed water flow to the plant, interrupted power supply and man power is required to check the water level in the plant and tank. To overcome this issue, an automatic drip irrigation system for drip irrigation or plant watering. It is also an automated system to fill the water tank also.

\section{IV.METHODOLOGY}

\section{A. Sensor Based Valve Operating System}

A sensor is a device, is to detect the changes in environmental and sends the information to processors. Different types of sensors are commonly used in various applications. All these sensors are used for measuring one of the physical properties like temperature, resistance, capacitance, heat transfer etc. Different types of sensors are listed below.

- Temperature sensor

- Proximity Sensor

- IR Sensor (Infrared Sensor) Pressure Sensor

- Light Sensor

- Ultrasonic Sensor

- Smoke, Gas and Alcohol Sensor

- Touch Sensor

- Humidity Sensor

- Flow and Level Sensor

The proposed automatic drip irrigation system is shown in the Fig. 6. 


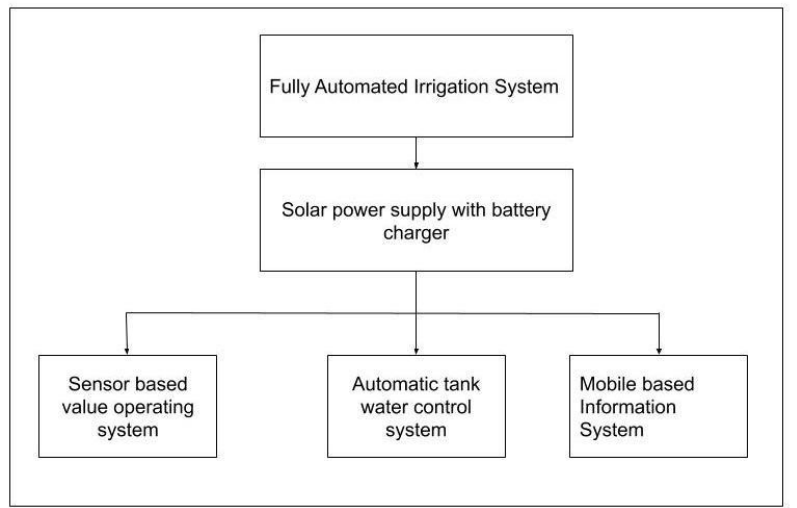

Fig 6 Methodology

\section{B. Soil moisture sensor}

It is a type of humidity sensor. Soil moisture sensor is used to measure water present in the soil indirectly by measuring the soil properties.

Soil moisture sensor has two probes. Both are used to measure thewater's volumetric content. The two probes permits current to passes through the soil and then it gets resistance value based on the soil type to measure the moisture content.

The soil has more water; the soil conducts more electricity and emits less resistance, so the moisture level is high. Dry soil contains less water than the electricity is poor, based on this principle the soil moisture sensor works.

\section{Solenoid valve}

Solenoid valves are mainly used for controlling the fluid flow automatically by the current. Solenoid valve works once they electrically energized or de-energized or also known as cut off or permit fluid flow. The actuator is an electromagnet. When the valve is energized, a magnetic field pulls a plunger against the spring. Likewise when de-energized, the plunger is returned to its original position by spring's action. They have five types

$$
\begin{aligned}
& \text { - Pilot-Operated Valve } \\
& \text { - Direct Acting Valve } \\
& \text { - } 2 \text { Way Valve } \\
& \text { - } 3 \text { Way Valve } \\
& \text { - } 4 \text { Way Valve }
\end{aligned}
$$

\section{D. .Direct Acting Valve}

It is normally in closed position; from the small orifice water will flow. The plunger is closed with a rubber gasket at its bottom. In a direct acting solenoid valve, the plunger is at down at normally by a small spring. By the ferromagnetic material the spring is made. The coil is electrically energized; a magnetic field lines are generated which pulls the plunger towards the centre. Valves parts are shown in Fig. 7

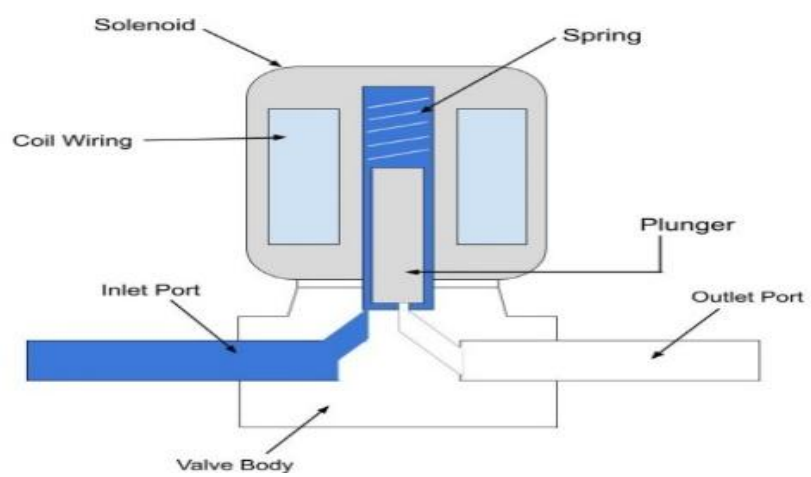

Fig 7 Parts of solenoid valve [12]

In this system a $12 \mathrm{~V}$ solenoid valve connected with Arduino UNO board. The moisture sensor is placed in a soil to detect the moisture content.

Table- I: Specifications of solenoid valve

\begin{tabular}{|c|c|}
\hline Specification & Description \\
\hline Model & $\begin{array}{l}12 \mathrm{~V} \text { DC 1/2" } \\
\text { Solenoid Valve }\end{array}$ \\
\hline Rated Operating Voltage & $12 \mathrm{~V}$ DC \\
\hline Rated Current & $0.6 \mathrm{~A}$ \\
\hline Operation Mode & Normally Closed \\
\hline Power Consumption & $8 \mathrm{~W}$ \\
\hline Pressure & $0.02-0.8 \mathrm{Mpa}$ \\
\hline Inlet and outlet Diameter & Hose barbs for \\
& $1 / 2 "$ (outer \\
& diameter) hose \\
\hline Dimensions (mm) & Body: 84 X 57mm \\
\hline L XWXH & Coil size: 34 X \\
\hline Weight (gm) & $23 \mathrm{~mm}$ \\
\hline Max fluid temperature & 48 \\
\hline
\end{tabular}

The sensor sense and send the information to Arduino then will operate valve as their condition. Valves specifications are given in the above Table I.

\section{E. Arduino UNO}

The Arduino UNO board is an open-source microcontroller board based on the Microchip ATmega328P microcontroller and it's developed by Arduino.cc. The board is consisting of analog and digital input/output pins that are connected for various boards and other circuits. The detailed pin out diagram is shown in the Fig. 8.

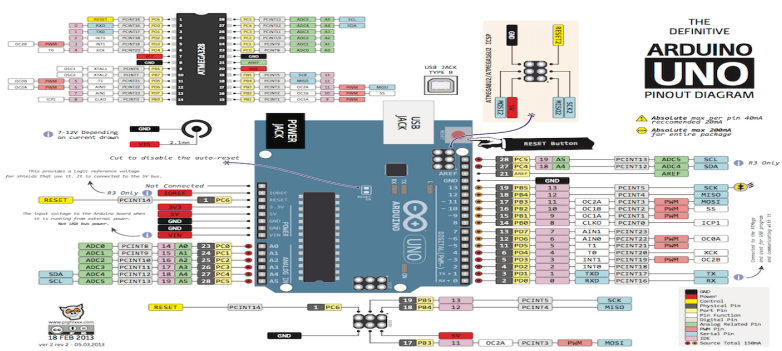

Fig 8 Arduino UNO Pinout diagram [11] 


\section{F. Automatic Tank Water Flow System}

A float switch is a type of level sensor, a device used to detect the water level in a tank. The switch may be used to control as an indicator, a pump, an alarm.

In this system the float switch is used to measure the water level in a tank. When water is below the par level it will automatically turn ON the Motor Switch. Again it reaches the par level it automatically turn OFF the Motor Switch.

Float switch sensor is placed at a maximum height of the tank. The float valve with cherry switch is shown in the Fig. 9.

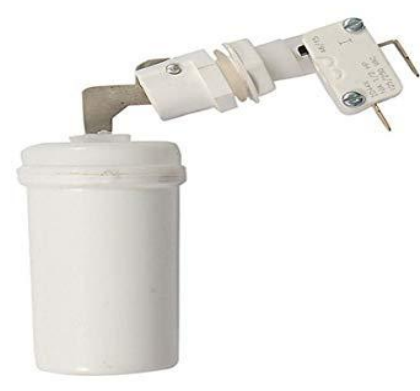

Fig 9 Float switch [14]

\section{G. Solar and Battery Based Power Supply}

Photovoltaic module takes light energy from the Sun to generate electric energy by the photovoltaic effect. The maximum of modules use the thin-film cells or wafer-based crystalline silicon cells. The structural member of a module can either be the both layers (top or back layer). Cells must also be protected from moisture and mechanical damage. Most of modules are stony, but semi-flexible modules are based on thin-film cells. The cells must be connected in series by one to another.

Photovoltaic modules are photovoltaic array of a PV plant that generates electric energy and its supplies to commercial and residential applications. $18 \mathrm{~W}$ of $12 \mathrm{~V}$ solar panel is used in this system.

Solar panel is connected with battery by a charging circuit for charging the battery. $12 \mathrm{~V}$ batteries are used in the system to store the solar energy.
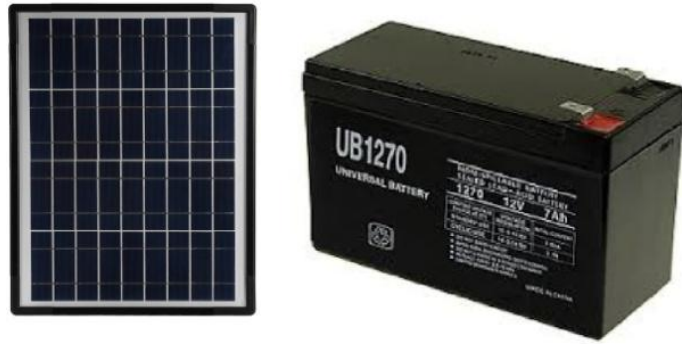

Fig 10 Solar and Battery [13]

\section{H. Mobile Based System}

In this system we used GSM SIM800L type.SIM800L is one type of cellular module which allows for GPRS transmission, SMS and making voice calls based on the application. It is more efficient like, low cost, small size and support quad band frequency and much more distance. Once the module is connecting with power module it boots up and searches for cellular network automatically.

GSM Module works with low power consumption and can transmit Voice, SMS and data information. It is slim and compact of customer design. With tiny size of $24 \times 24 \times 3 \mathrm{~mm}$. The general specifications are shown in the Table II

Table-II: Specifications of SIM module800

\begin{tabular}{|c|c|}
\hline Specifications & Description \\
\hline Quad-band & $\begin{array}{l}\text { 850/900/1800/1900 } \\
\mathrm{MHz}\end{array}$ \\
\hline Dimensions & $24.0 * 24.0 * 3.0 \mathrm{~mm}$ \\
\hline Weight & $3.14 \mathrm{~g}$ \\
\hline $\begin{array}{l}\text { Supply voltage } \\
\text { range }\end{array}$ & $3.4 \sim 4.4 \mathrm{~V}$ \\
\hline $\begin{array}{l}\text { Operating } \\
\text { temperature }\end{array}$ & $-40^{\circ} \mathrm{C} \sim 85^{\circ} \mathrm{C}$ \\
\hline
\end{tabular}

In this system GSM module is used to receive an alert message whenever the system is ON and OFF, GSM module sends the notification to the corresponding admin.

The autonomous drip irrigation system was developed by the application of the Internet of Things, Arduino board and solar energy power.

\section{Advantages and Applications}

The wastage of the water is main problem in the agriculture and gardening filed. So this Automatic drip irrigation with solar energy power system will help to minimize the water wastage in agriculture field and maintain the required moisture for planting the tree, crops etc.

i) The application of Automatic drip irrigation system is used to develop the automatic water feeding system on the road side tree planting.

ii) This Automatic Drip irrigation system will leads to reduce the manpower required for water feeding to the plants.

iii) This Automatic Drip irrigation system will reduce the total time required for water feeding to the garden or field.

\section{RESULT AND DISCUSSION}

In this Automatic Drip Irrigation system is fully automated from water filling in the tank to irrigating crops by Arduino, solar panel and battery powered system. Solenoid valve is placed in the tank outlet. Fig. 11 shows the overall layout of the automatic drip irrigation system. 


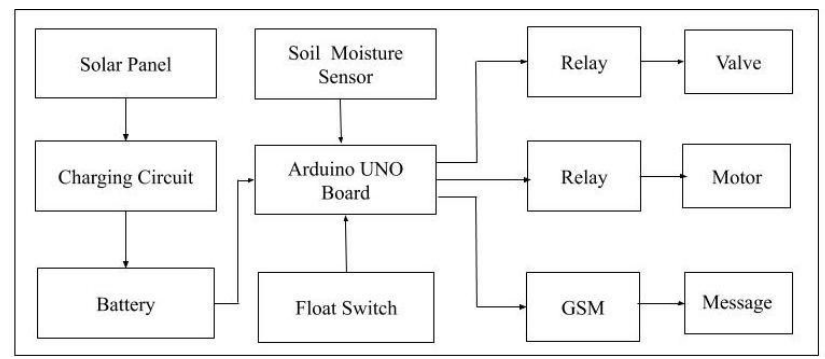

Fig 11 Layout of Automated Drip Irrigation System

In this system solar panel converts the solar energy into electrical energy by using photovoltaic cells and the energy is store in the battery, which supplies the required power for the boards.

The entire system consists of Arduino board, battery, soil sensor, float switch are input and the outputs are relay board, GSM module.

Soil moisture sensor detects the humidity in the soil and sends to Arduino board. Similarly the floats switch sensor respond based on the water level in the tank.

Based on the inputs from the soil moisture sensor the valve can be opened / closed automatically based on the requirement. Also based on the GSM module also the motor / value can be operated. Based on the float switch input the motor can be switched ON/OFF to fill the water tank as per the requirement.

\section{VI.CONCLUSION}

Automatic irrigation system is designed by using the Arduino board, solenoid valve, soil moisture sensor and solar panel. This automatic irrigation system senses the moisture content of the soil and automatically switches the solenoid valve and the power is supplied from the battery and the battery is charged by the solar panel. The float switch is used to monitor the water level in the overhead tank. The GSM module sends the message, whenever the valve is turn ON and OFF. In this complete automatic system is to reduce the soil erosion, provide uniform water flow, no man power requirement, less space is required, provide the necessary moisture to the plant continuously without conventional electric power. Only model is designed in this automatic drip irrigation system. By using the same concept the actual drip irrigation may be designed very easily. Instead of monitoring water tank automatically pump the water from the well or bore well.

\section{REFERENCES}

1. Moriarty and P. Michael, "Solar receiver-based power generation system." U.S. Patent No. 6,668,555,2017.

2. F. A. Costello, J. L. Manniso, A., J. DiPinto, and G. W. Smith, "Solar Heating System," U.S. Patent No. 4,055,163. Washington, DC: U.S. Patent and Trademark Office, 1977.

3. V. Raghunathan, A. Kansal, Hsu and B. Jasonetal, "Design Consideration For Solar Energy Harvesting Wireless Embedded System" In Proceeding of the 4th international symposium on Information processing in sensor networks, (pp. 64), IEEE Press,2015.

4. Jr. Northrup and L. Leonard, "Compound lens solar energy system" U.S. Patent No. 4,022,186,1977.

5. Shaikh Abdullah, Al MamunHossain and Wang Lixue, "Contemporary Perspective of Drip Irrigation: A Review of Water Saving Crop Production" A Review of Saving Crop Production,2018.

6. Saeed Mohammed Wazeda and Ben Richard Hughesa, "A review of sustainable solar irrigation systems for Sub-Saharan Africa," Renewable and sustainable Energy reviews, pp 81, 1206-1225,2018.

7. S. Postel, P. Polak, F. Gonzales, \& J. Keller, "Drip irrigation for small farmers: A new initiative to alleviate hunger and poverty,"Water International, 26(1), 3-13,2001.

8. R. Gayathri, E. Roshith, B. S. Roshini, S. Murugan, \& S. Priya, "Implementation of Arduino based Enhanced Fingerprint Biometric System for Secured Data Exchange". International Journal of Computational Intelligence Research 13.8 , 2113-2123,2017.

9. C. McNally, "Arduino based wireless power meter," MS design project, Cornell University, Ithaca, NY,2010.

10. S. Anwaarullah, \& S. V. Altaf, "RTOS based home automation system using Android" international journal of advanced Trends in computer science and engineering, 2(1), 480-484,2013.

11. Source:MarcusJenkins1998,http://marcusjenkins.com/arduino-pinoutdi agrams/

12. https://valveproducts.net/solenoid-valve/9-basis-parts-of-a-solenoid-val ve

13. https://www.solaralliance.org/solar-rechargeable-batteries/

14. https://www.majju.com/product/water-or-liquid-level-sensor-float-swit $\mathrm{ch} /$

15. http://www.yourarticlelibrary.com/irrigation/top-3-methods-of-irrigatio n-with-diagram/60659

16. https://www.researchgate.net/publication/282896700_Effect_of_Defici t_Irrigation_on_the_Growth_Water_Use_Characteristics_and_Yield_o f_Cotton_in_Arid

\section{AUTHORS PROFILE}

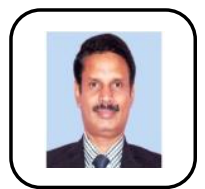

Dr. P. Venkumar, is currently a Senior Professor in Department of Mechanical Engineering, Kalasalingam Academy of Research and Education, Krishnankovil, Tamilnadu, Inida. He received his B.E., and M.E., degrees in Thigagrajar College of Engineering, Madurai, Tamilnadu, India, in 1994 and 1997, respectively and Ph.D. degree in Manonmaniam Sundaranar University, India in Industrial Engineering in 2006. His main areas of research interest are Manufacturing system optimization, Supply chain management and Smart manufacturing.

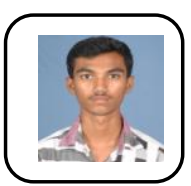

K. Sureshkrishna, He received his B.Tech. degree Department of Mechanical Engineering in Kalasalingam Academy of Research and Education, Krishanankovil, Tamil Nadu, India in 2019.

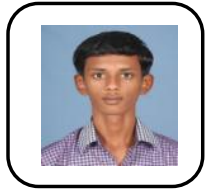

N. Vignesh, He received his B.Tech. degree Department of Mechanical Engineering in Kalasalingam Academy of Research and Education, Krishanankovil, Tamil Nadu, India in 2019

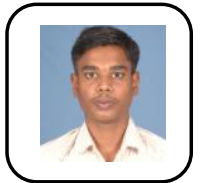

P. Sundharamoorthy, He received his B.Tech. degree Department of Mechanical Engineering in Kalasalingam Academy of Research and Education, Krishanankovil, Tamil Nadu, India in 2019.

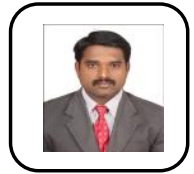

Dr. E. Muthu Kumaran received his Bachelors, Masters and Ph.D Degrees in Electronics and Communication Engineering from from Anna University, Chennai in 2005, 2008 and 2015 respectively. He is having more than 14 years of teaching and research experience worked in various engineering colleges and universities. Currently he is a Assistant Professor in Dr.B.R.Ambedkar Insitute of Technology, Port Blair, Andaman and Nicobar Islands, India. He has undertaken various funded major research projects and published research papers in various International and national journals. His research interests include Medical Electronics, Bio Inspired Algorithms, IoT, Instrumentation and VLSI.

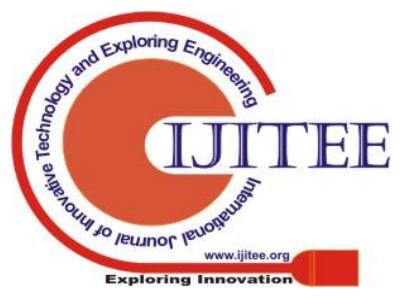

